\title{
Dinoflagellate cysts from the Pannonian (late Miocene) "white marls" in Pécs-Danitzpuszta, southern Hungary
}

\author{
${ }^{1}$ KrizManić, Krešimir, ${ }^{2}$ Sebe, Krisztina, ${ }^{3,4}$ MagYaR, Imre \\ 'INA - Oil Company Plc., Exploration \& Production, Exploration \& Upstream portfolio development, 10000 Zagreb, Lovinčićeva 4, Croatia; \\ kresimir.krizmanic@ina.hr \\ ${ }^{2}$ University of Pécs, Department of Geology and Meteorology, 7624 Pécs, Ifjúság útja 6, Hungary; sebe @ gamma.ttk.pte.hu, \\ ORCID: 0000-0002-4647-2199
}

${ }^{3}$ MOL Hungarian Oil and Gas Plc., 1117 Budapest, Október huszonharmadika u. 18, Hungary; immagyar@ mol.hu, ORCID: 0000-0002-9236-0040 ${ }^{4}$ MTA-MTM-ELTE Research Group for Paleontology, Budapest, Hungary

\section{Dinoflagelláta ciszták Pécs-Danitzpuszta pannóniai „,fehér márgájából”}

Összefoglalás

A késő neogén Pannon-tó üledékeinek rétegtani tagolásában és korrelációjában fontos szerepet játszanak a szerves vázú mikroplanktonhoz tartozó dinoflagelláták cisztái. A pécs-danitzpusztai homokbánya pannóniai mészmárga rétegsorából 66 palinológiai preparátumot vizsgáltunk az üledékek rétegtani helyzetének és korának megállapítása céljából. E fontos feltárásból korábbi vizsgálatok sikertelenül próbáltak dinoflagelláta cisztákat kinyerni. Az új gyújtésből 6 minta tartalmazott jó megtartású palinomorfákat. A rétegsor aljából vett mintában (D25) valószínúleg áthalmozott középsô miocén együttes volt. A középsố szakasz mintái (D3, D2, D1) a Pontiadinium pecsvaradensis zónát jelezték (kb. 10,810,6 M év). A márgák felső részéből vett minták (D219, D221) nem adtak további rétegtani információt, a Pontiadinium pecsvaradensis zónába tartoznak vagy annál fiatalabbak. A középső és felső szakasz mintáinak palinofáciese (D3-tól D221-ig) a szárazföldi behordástól távoli, nyugodt, alkalmanként oxigénszegény, valószínúleg mélyvízi üledékképződési környezetet jelez.

Kulcsszavak: Mecsek, pannóniai, palinológia, dinoflagelláta ciszta, biosztratigráfia

\begin{abstract}
Dinoflagellate-cyst based biostratigraphy is an important tool in the stratigraphical subdivision and correlation of the Neogene Lake Pannon deposits. A total of 66 palynological samples were investigated from the Pannonian (upper Miocene) marl succession exposed in the Pécs-Danitzpuszta sand pit in order to evaluate the biostratigraphical assignment and constrain the age of the strata. Earlier attempts to recover dinoflagellate cysts from this important reference section had failed. In our material, six samples contained well-preserved palynomorphs. One sample from the lower part of the succession (D25) contained a probably reworked middle Miocene assemblage. Samples from the middle segment of the succession (D3, D2, D1) indicate the Pontiadinium pecsvaradensis Zone (ca. 10.8 to $10.6 \mathrm{Ma}$ ). Samples from the top of the marl (D219, D221) did not give additional stratigraphic information ( $P$. pecsvaradensis Zone or younger). The palynofacies of samples D3 to D221 indicates a relatively distal, calm, occasionally oxygen-deficient, probably deep depositional environment.
\end{abstract}

Keywords: Mecsek Mts, Pannonian, palynology, dinoflagellate cysts, biostratigraphy

\section{Introduction}

Pannonian (late Miocene) "white marls", deposited in regions sheltered from siliciclastic sediment input in Lake Pannon, are widely distributed in the southern part of the Pannonian Basin. Having accumulated in an isolated water body, their stratigraphic subdivision is problematic and relies on a few groups of the endemic biota. Their fossil mol- luscs have been studied and utilized for biostratigraphy for over a century (e.g., GORJANOVIĆ-KRAMBERGER 1890, 1899; Koch 1902; SREMAC 1981; VRSALJKo 1999; TER Borgh et al. 2013). The organic-walled microplankton, first of all dinoflagellate cysts and prasinophytes (green algae), also provide good stratigraphic markers in Lake Pannon deposits, but they are scarcely known from the "white marls." A rich dinoflagellate cyst assemblage was reported from the 
Našice outcrop in Slavonia, northeast Croatia, by BAKRAČ (2005) and BAKRAČ in VASILIEV et al. (2007), and some dinoflagellate cysts were presented from boreholes in SE Hungary by SÜTŐ-SZENTAI in MAGYAR et al. (2004). Apart from these data, we are not aware of published dinoflagellate cyst assemblages from the Pannonian "white marls."

The objective of this paper is the investigation of dinoflagellate cysts from the largest surface exposure of these rocks in Hungary, Pécs-Danitzpuszta, in order to provide biostratigraphic and additional paleoenvironmental data for the integrated stratigraphic evaluation of the section. Earlier attempts to recover dinoflagellate cysts from the layers of this outcrop all failed, but as our pilot samples gave promising results, a large set of samples was collected and investigated. Earlier dinoflagellate studies from drill cores in the neighbouring regions of SW Hungary (SÜTŐ-SZENTAI 1982, 1989, 1994, 2000a, 2002) and the Drava basin (INA industrial reports by K. KRIZMANIĆ) provided a firm basis for the biostratigraphic evaluation of the dinoflagellate assemblages.

The complex sedimentological and paleontological investigation of the Pécs-Danitzpuszta Neogene sequence was supported by a Croatian-Hungarian bilateral research project; our brief report on the dinoflagellates of the marls is a contribution to this joint effort.

\section{Geological setting}

The outcrop is a sand pit, located within the administrative area of Pécs, in the eastern outskirts of the city (Figure 1). The pit, together with an exploratory trench excavated in its northwestern margin, expose a strongly tilted Badenian-
Sarmatian-Pannonian marl-dominated succession in $80 \mathrm{~m}$ stratigraphic thickness, capped by Pannonian sands (SEBE et al. 2021).

\section{Sampling, material and methods}

During a field trip in 2017, two pilot samples were taken randomly for palynological analysis from the easily accessible uppermost part of the marl succession (Layers D219 and D221) (Figure 1). As the samples yielded a well-preserved dinoflagellate cyst association, the entire section was sampled in two steps. A total of 72 samples (D72 to D1) were taken from the Badenian-Pannonian succession exposed in the exploratory trench, representing the lower $37 \mathrm{~m}$ of the section (Figure 1). Forty-one samples were chosen for palynological preparation and subsequent palynological and palynofacies analysis. However, only four samples, all belonging to the Pannonian, contained dinoflagellate cysts, and only three were suitable for biostratigraphical and environmental interpretation. The upper part of the Pannonian marl succession (D101 to D226, representing $43 \mathrm{~m}$ stratigraphic thickness) was investigated in 23 samples. All slides were barren except sample D225 that contained an impoverished, poorly preserved dinoflagellate cyst assemblage. Due to their poor preservation the biostratigraphic or paleoecological evaluation was not possible.

Processed in the standard way of palynological maceration (Moore et al. 1991), rock samples were washed in 7\% hydrochloric acid $(\mathrm{HCl})$, dried and ground in a laboratory crusher, weighed $(100 \mathrm{~g})$ and set for dissolution of carbonates (with $18 \% \mathrm{HCl}$ ) and silicates (with $40 \% \mathrm{HF}$ ). The organic residue
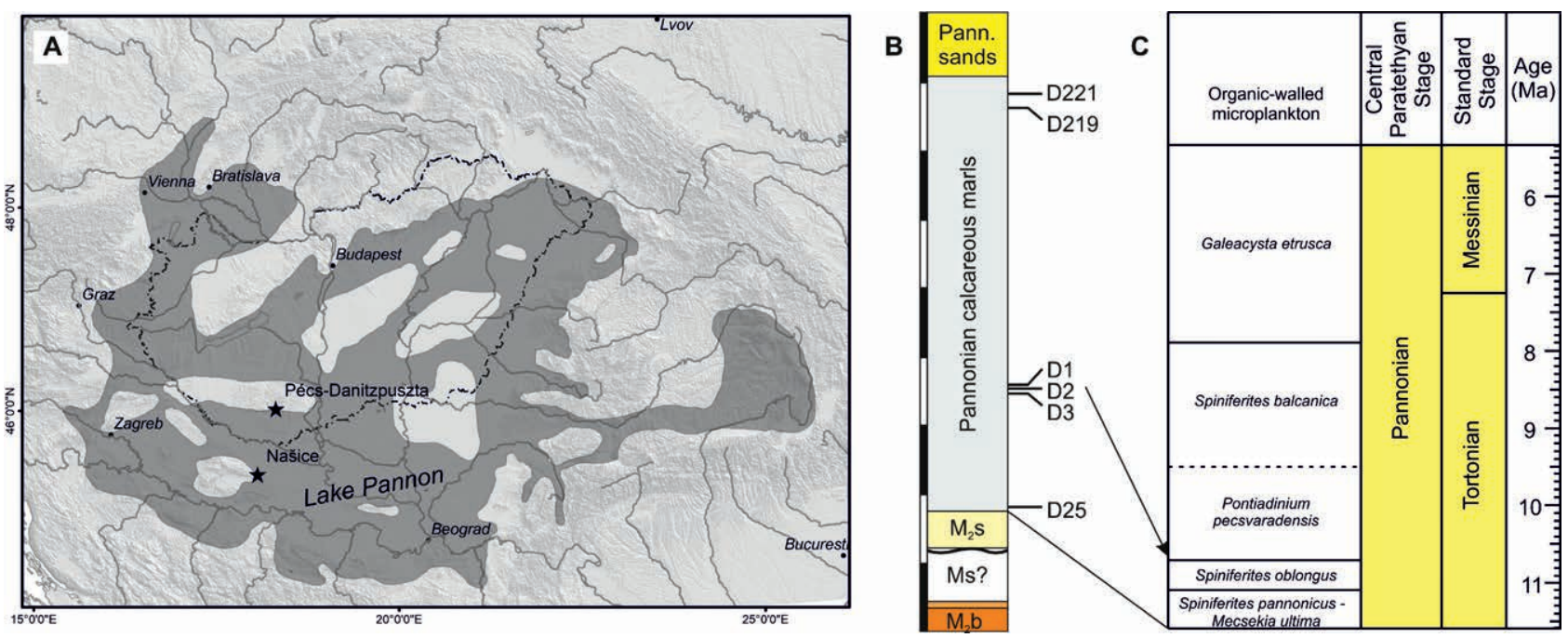

Figure 1. Location of the study area within the Pannonian Basin and stratigraphical position of the palynological samples from Pécs-Danitzpuszta. A: Location of the sand pit; dark patch indicates extent of Lake Pannon at 10.8 Ma after MAGYAR et al. (1999a). B: Simplified stratigraphic log of the sand pit with sample positions. Each segment of the vertical scale represents $10 \mathrm{~m}$ (the entire section is $90 \mathrm{~m}$ ). C: Organic-walled microplankton zonation of Lake Pannon sediments (based on SÜTÖ-SZENTAI 1988, 2000b and BAKRAČ et al. 2012, and modified according to exploration borehole data from Croatia)

1. ábra. Helyszinrajz és rétegoszlop. A: A pécs-danitzpusztai feltárás helyzete a Pannon-medencében, sötéttel a Pannon-tó elterjedése kb. 10,8 millió évvel ezelött (MAGYAR et al. 1999 a szerint). B: A feltárás egyszerüsitett rétegoszlopa a produktív minták helyével. A függöleges skála minden szegmense 10 métert képvisel, a teljes rétegoszlop 90 m vastag. C: A Pannon-tó üledékeinek szervesvázú mikroplankton zonációja SüTŐNÉ SZENTAI (1988, 2000b) és BAKRAČ et al. (2012) alapján, a horvátországi szénhidrogénkutató fúrások adatai alapján módositva 
was separated from undissolved inorganic mixture by treatment with a heavy liquid $\left(\mathrm{ZnCl}_{2}\right.$, s.g. $\left.2.1 \mathrm{~kg} / \mathrm{l}\right)$ and sieved through a $15 \mathrm{~mm}$ sieve. Finally, palynological slides were prepared using glycerin gelatin as the mounting medium.

Palynological slides were analysed by a Leitz Aristoplan light microscope and an Olympus DP 25 digital camera with the corresponding Stream Motion software for photography and documentation. An Olympus BX51 fluorescence light microscope was used for palynofacies characterisation and control of reworked palynomorphs.

For each sample, the Thermal Alteration Index (TAI) was determined. This is part of a visual kerogene analysis (SCHWAB 1990) where the colour of different palynofacies constituents, including sporomorphs, dinoflagellate cysts, acritarchs etc. under the transmitted light is expressed on a ten-step scale $(1,1+, 2-, 2,2+, 3-, 3,3+, 4-, 4)$. The colour is a function of paleotemperature, pressure, and geologic age, as well as that of structure, thickness, chemical composition and weathering of palynomorphs. The degree of thermal maturity is defined by colour change from pale yellow through brown to black (e.g., STAPLIN 1977).

Palynostratigraphic evaluation of the identified dinoflagellate cysts was based on the relevant literature (e.g., SÜTóSZENTAI 1988, 2000b; LUČIĆ et al. 2001; BAKRAČ 2005; BAKRAČ et al. 2012; SOLIMAN \& RIDING 2017) and on our own experience (K. K.) from hydrocarbon exploration boreholes in Croatia.

\section{Results}

The palynofacies and palynological assemblages of the samples are described in stratigraphic order, from bottom to top. The identified taxa are listed in Table I. Palynofacies and selected dinoflagellate cysts are illustrated in Figures 2 and 3.

\section{Layer D25}

Sample D25 contains abundant sedimentary organic particles in the rock macerate. Amorphous organic matter particles are rare in the palynofacies. Lignohumine clasts are mostly made up of smaller, black, fully oxidized woody fragments (inertinite). Liptinite components are abundant. They include some pollen grains and a lot of various, completely oxidized (transparent) dinoflagellate cysts. In the palynofacies, a significant amount of macerals is composed of bigger, brown, biostructured phytoclasts (vitrinite) and cuticles, both immature (TAI 1-2). The most frequent dinoflagellate cysts are Lingulodinium machaerophorum (DEFLANDRE \& Cookson, 1955) Wall, 1967 (Figure 2A), Polysphaeridium zoharyi (RossignOL, 1962) BUJAK et al., 1980 (Figure 2B), Spiniferites sp., Achomosphaera sp., Operculodinium sp., Hystrichokolpoma sp. and Selenopemphix sp. (Table I).

Table I. Dinoflagellate cysts and green algae identified in the Pécs-Danitzpuszta samples

I. táblázat. A pécs-danitzpusztai szelvény mintáiból meghatározott dinoflagelláta ciszták és zöldalgák

\begin{tabular}{|l|c|c|c|c|c|c|}
\hline & $\mathrm{D} 25$ & $\mathrm{D} 3$ & $\mathrm{D} 2$ & $\mathrm{D} 1$ & $\mathrm{D} 219$ & $\mathrm{D} 221$ \\
\hline Lingulodinium machaerophorum & $\mathrm{X}$ & & & & & \\
\hline Polysphaeridium zoharyi & $\mathrm{X}$ & & & & & \\
\hline Spiniferites pannonicus & & $\mathrm{X}$ & $\mathrm{X}$ & $\mathrm{X}$ & $\mathrm{X}$ & $\mathrm{X}$ \\
\hline Spiniferites oblongus & & $\mathrm{X}$ & $\mathrm{X}$ & $\mathrm{X}$ & $\mathrm{X}$ & $\mathrm{X}$ \\
\hline Spiniferites hennersdorfensis & & $\mathrm{X}$ & $\mathrm{X}$ & $\mathrm{X}$ & $\mathrm{X}$ & $\mathrm{X}$ \\
\hline Spiniferites maisensis & & & & & & $\mathrm{X}$ \\
\hline Spiniferites bentorii granulatus & & & & & $\mathrm{X}$ & \\
\hline Spiniferites sp. & $\mathrm{X}$ & & $\mathrm{X}$ & $\mathrm{X}$ & & \\
\hline "Virgodinium asymmetricum" & & $\mathrm{X}$ & $\mathrm{X}$ & $\mathrm{X}$ & $\mathrm{X}$ & $\mathrm{X}$ \\
\hline "Virgodinium foveolatum" & & & $\mathrm{X}$ & & & $\mathrm{X}$ \\
\hline "Virgodinium" sp. & & & $\mathrm{X}$ & & & \\
\hline Pontiadinium pecsvaradensis & & $\mathrm{X}$ & $\mathrm{X}$ & $\mathrm{X}$ & & $\mathrm{X}$ \\
\hline Pontiadinium obesum & & & & & & $\mathrm{X}$ \\
\hline Pontiadinium sp. & & & $\mathrm{X}$ & & & \\
\hline Impagidinium globosum & & & $\mathrm{X}$ & & & \\
\hline Impagidinium spongianum & & & $\mathrm{X}$ & & & \\
\hline Impagidinium sp. & & $\mathrm{X}$ & $\mathrm{X}$ & $\mathrm{X}$ & $\mathrm{X}$ & $\mathrm{X}$ \\
\hline Selenopemphix sp. & $\mathrm{X}$ & & & & & $\mathrm{X}$ \\
\hline Nematosphaeropsis sp. & & & & $\mathrm{X}$ & & $\mathrm{X}$ \\
\hline Achomosphaera sp. & $\mathrm{X}$ & & & $\mathrm{X}$ & & \\
\hline Operculodinium sp. & $\mathrm{X}$ & & & $\mathrm{X}$ & & \\
\hline Hystrichokolpoma sp. & $\mathrm{X}$ & & & & & \\
\hline Chytroeisphaeridia sp. & & & $\mathrm{X}$ & & & \\
\hline Spirogyra sp. & & $\mathrm{X}$ & $\mathrm{X}$ & $\mathrm{X}$ & $\mathrm{X}$ & $\mathrm{X}$ \\
\hline Botryococcus braunii & & $\mathrm{X}$ & $\mathrm{X}$ & $\mathrm{X}$ & $\mathrm{X}$ & $\mathrm{X}$ \\
\hline
\end{tabular}



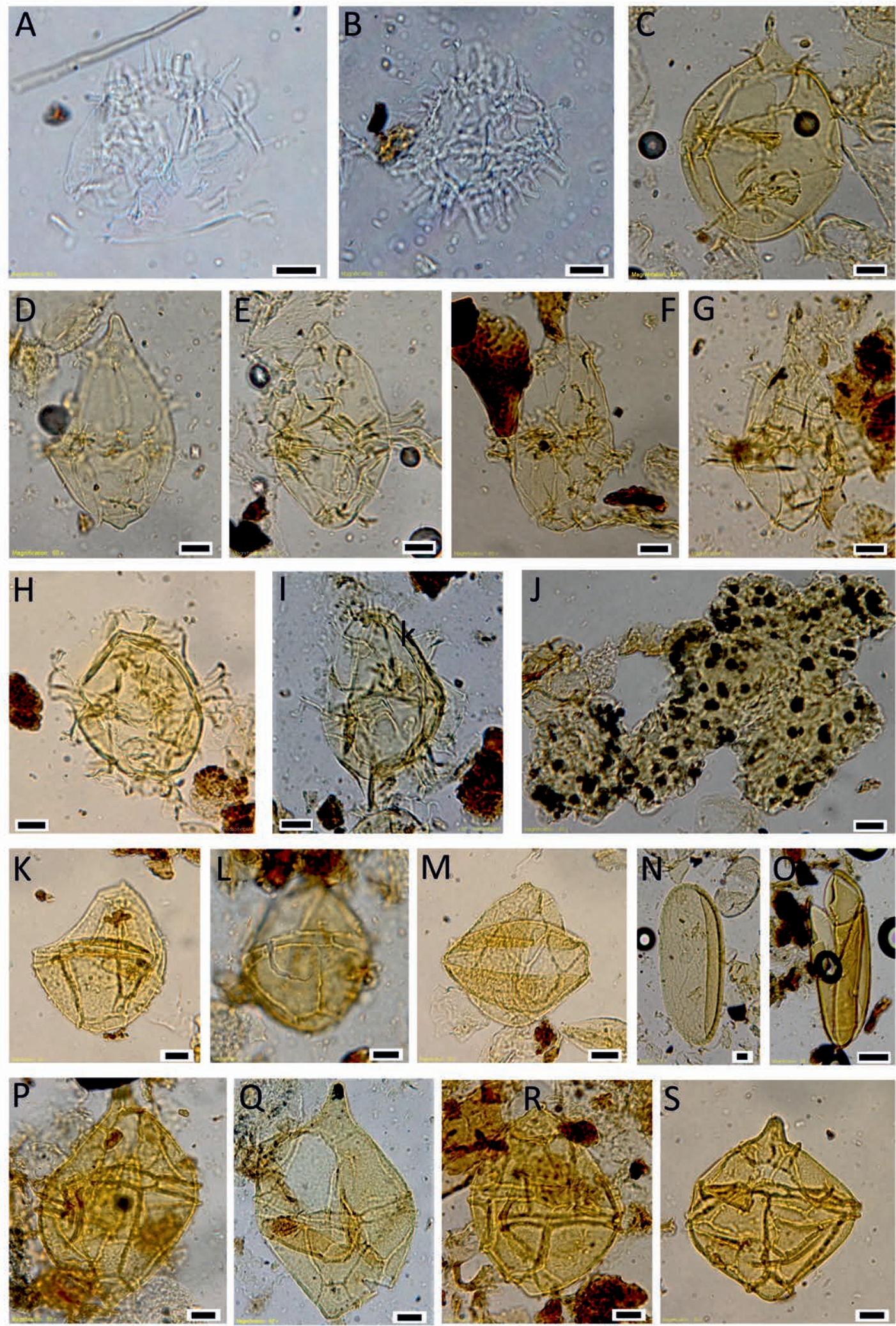

Figure 2. Selected Pannonian dinoflagellate cysts and green algae from the Pécs-Danitzpuszta outcrop. The black scale bars represent $10 \mu \mathrm{m}$ for each figure.

A: Lingulodinium machaerophorum (DeflandRe \& Cookson, 1955) Wall 1967, D25; B: Polysphaeridium zoharyi (Rossignol, 1962) BujaK et al. 1980, D25 C: Spiniferites pannonicus (Sütö-SzENTAI, 1986), Soliman \& Riding 2017 (D219); D-G: Spiniferites oblongus (SüTő-SzENTAI, 1986) Soliman \& Riding 2017 (D, E: D219; F: D221; G: D3); H, I: Spiniferites hennersdorfensis SolimAn \& Riding, 2017 (H: D221; I: D1); J: Botryococcus braunii KützING, 1849 (D221); K, L: "Virgodinium asymmetricum” SüTö-SzENTAI, 2010 (D221); M: “Virgodinium foveolatum” SüTö-SzENTAI, 1982 (D221); N: Spirogyra sp. Type II (D219); O Spirogyra sp. Type I(D221); P-R: Pontiadinium pecsvaradensis SüTő-SzENTAI, 1982 (P: D221; Q: D1; R: D3); S Pontiadinium obesum SüTő-SzENTAI, 1982 (D221) 2. ábra. Pannóniai dinoflagelláta ciszták és zöldalgák a pécs-danitzpusztaifeltárásból. Afekete aránymérték mindegyik képen 10 um-nek felel meg 


\section{Layer D3}

The macerate of the rock sample is very rich in sedimentary organic matter. About $50 \%$ of the palynofacies is composed of amorphous organic matter. Lignohumine clasts make up about $20 \%$ of the organic residue composed mostly of brown, bigger, biostructured phytoclasts (vitrinite) and fewer black (inertinite) kerogen clasts. About 30\% of the palynofacies is liptinite component made up of dinoflagellate cysts, green algae remnants (Spirogyra sp. and Botryococcus braunii KüTZING, 1849) and different spores and pollen grains. Macerals are immature (TAI 2). The most frequent dinoflagellate cysts are Spiniferites pannonicus (Sütő-SzEntai, 1986), Soliman \& RIDING, 2017, Spiniferites oblongus (SÜTŐ-SzENTAI, 1986) SOLIMAN \& RIDING, 2017 (Figure 2G), Spiniferites hennersdorfensis SolIMAN \& RIDING, 2017, Impagidinium sp., "Virgodinium asymmetricum” Sütó-SZENTAI, 2010 and Pontiadinium pecsvaradensis Sütő-SzEnTAI, 1982 (Figure 2R) (Table I).

\section{Layer D2}

The sample is very rich in sedimentary organic matter (Figure 3A). Amorphous organic matter particles are predominant (ca. 50\%). Lignohumine clasts make up ca. 10\% of the palynofacies and they are mostly composed of black (inertinite) clasts. The liptinite component represents about $40 \%$ of the visible organic residue and it is made up of diverse chorate and proximate (dominant) dinoflagellate cysts, green algae remnants (abundant Spirogyra sp., Botryococcus braunii KüTZING, 1849), spores and assorted pollen grains (mostly bisaccate conifer pollen). Macerals are immature (TAI 1-2).

Dinoflagellate cysts are represented mainly by Spiniferites pannonicus (Sütő-SzEnTAI, 1986), SOLIMAN \& RIDING, 2017, Spiniferites oblongus (SÜTŐ-SzENTAI, 1986) SolimAN \& RIDING, 2017, Spiniferites hennersdorfensis Soliman \& RIDING, 2017, Spiniferites sp., Impagidinium globosum SüTŐ-SZENTAI, 1985, Impagidinium spongianum SüTô-SZENTAI, 1985, Impagidinium sp., Chytroeisphaeridia sp., "Virgodinium foveolatum" SÜTŐ-SzENTAI 1982, "Virgodinium” sp., "Virgodinium asymmetricum” SÜTŐ-SzENTAI, 2010, Pontiadinium pecsvaradensis SüTő-SzENTAI, 1982 and Pontiadinium sp. (Table I).

\section{Layer D1}

The sample is very rich in sedimentary organic matter. Amorphous organic matter makes up about 50\% and lignohumine clasts about $20 \%$ of the palynofacies. The liptinite component is abundant and comprises $30 \%$ of the visible organic residue. The palynological assemblage is composed of diverse chorate and proximate (predominant) dinoflagellate cysts, green algae remnants (Spirogyra sp., Botryococcus braunii KüTZING, 1849), spores and various pollen grains (mainly bisaccate). Pyrite inclusions in palynomorphs are common. Macerals are mechanically damaged and immature
(TAI 1-2). The most frequent dinoflagellate cysts are Spiniferites pannonicus (SÜTŐ-SZENTAI, 1986), SOLIMAN \& RIDING, 2017, Spiniferites oblongus SüTő-SzENTAI, 1986, Spiniferites hennersdorfensis SOLIMAN \& RIDING, 2017 (Figure 2I), Spiniferites sp., Achomosphaera sp., Nematosphaeropsis sp., Operculodinium sp., Impagidinium sp., "Virgodinium asymmetricum" SÜTő-SZENTAI, 2010 and Pontiadinium pecsvaradensis SüTŐ-SzENTAI, 1982 (Figure 2Q) (Table I).

\section{Layer D219}

The rock sample is very rich in sedimentary organic matter (Figure 3B, C). About $50 \%$ of the organic particles are represented by amorphous organic matter. Lignohumine clasts make up about $40 \%$ of the organic residue and it is composed mostly of smaller, black, opaque, completely oxidized woody tissue (inertinite). About $10 \%$ of the palynofacies is liptinite component made of diverse chorate and proximate dinoflagellate cysts, green algae remnants e.g., Spirogyra sp. Type II (Figure 2N) and Botryococcus braunii KüTZING, 1849, various spores and abundant pollen grains. Macerals are mechanically damaged and contain no pyrite inclusions. The most numerous dinoflagellate cysts are Spiniferites pannonicus (SÜTó-SzENTAI, 1986), SOlimAn \& RIDING, 2017 (Figure 2C), Spiniferites bentorii granulatus FUCHS \& SÜTŐ-SZENTAI, 1991, Spiniferites oblongus (SüTő-SzENTAI, 1986) Soliman \& RIDING, 2017 (Figure 2D, E), Spiniferites hennersdorfensis SOLIMAN \& RIDING, 2017, "Virgodinium asymmetricum” SüTŐ-SZENTAI 2010 and Impagidinium sp. (Table I).

This sample is colloquially referred to as the Myrtle facies because of the abundant Myrica leaves found in this layer (HABLY \& SEBE 2016).

\section{Layer D221}

The sample is very rich in sedimentary organic matter (Figure 3D, E). Amorphous organic matter particles make up about $50 \%$, and lignohumine kerogene clasts form $20 \%$ of the palynofacies. Lignohumine clasts are mainly largesized brown, biostructured phytoclasts (vitrinite) and smaller black clasts (inertinite). About $30 \%$ of the organic residue is liptinite kerogen component composed of diverse chorate and proximate dinoflagellate cysts, green algae remnants Spirogyra sp. Type I (Figure 2O) and Botryococcus braunii KüTZING, 1849 (Figure 2J), and rare spores and pollen grains (mostly bissacate).

The most common dinoflagellate cysts are Spiniferites pannonicus (SÜTő-SzENTAI, 1986), SOLIMAN \& RIDING, 2017, Spiniferites oblongus (SÜTő-SzENTAI, 1986) Soliman \& RIDING, 2017 (Figure 2F), Spiniferites hennersdorfensis SOLIMAN \& RIDING, 2017 (Figure 2H), Spiniferites maisensis Sütő-SzEnTAI, 1994, Selenopemphix sp, Nematosphaeropsis sp., "Virgodinium asymmetricum" SüTő-SzENTAI, 2010 (Figure 2K, L), Impagidinium sp., "Virgodinium foveolatum" SüTő-SzEnTAI, 1982 (Figure 2M), Pontiadinium obesum SüTÓ-SZENTAI, 1982 (Figure 2S) and Pontiadinium pecsvaradensis SÜTŐ-SzENTAI, 1982 (Figure 2P) (Table I). 

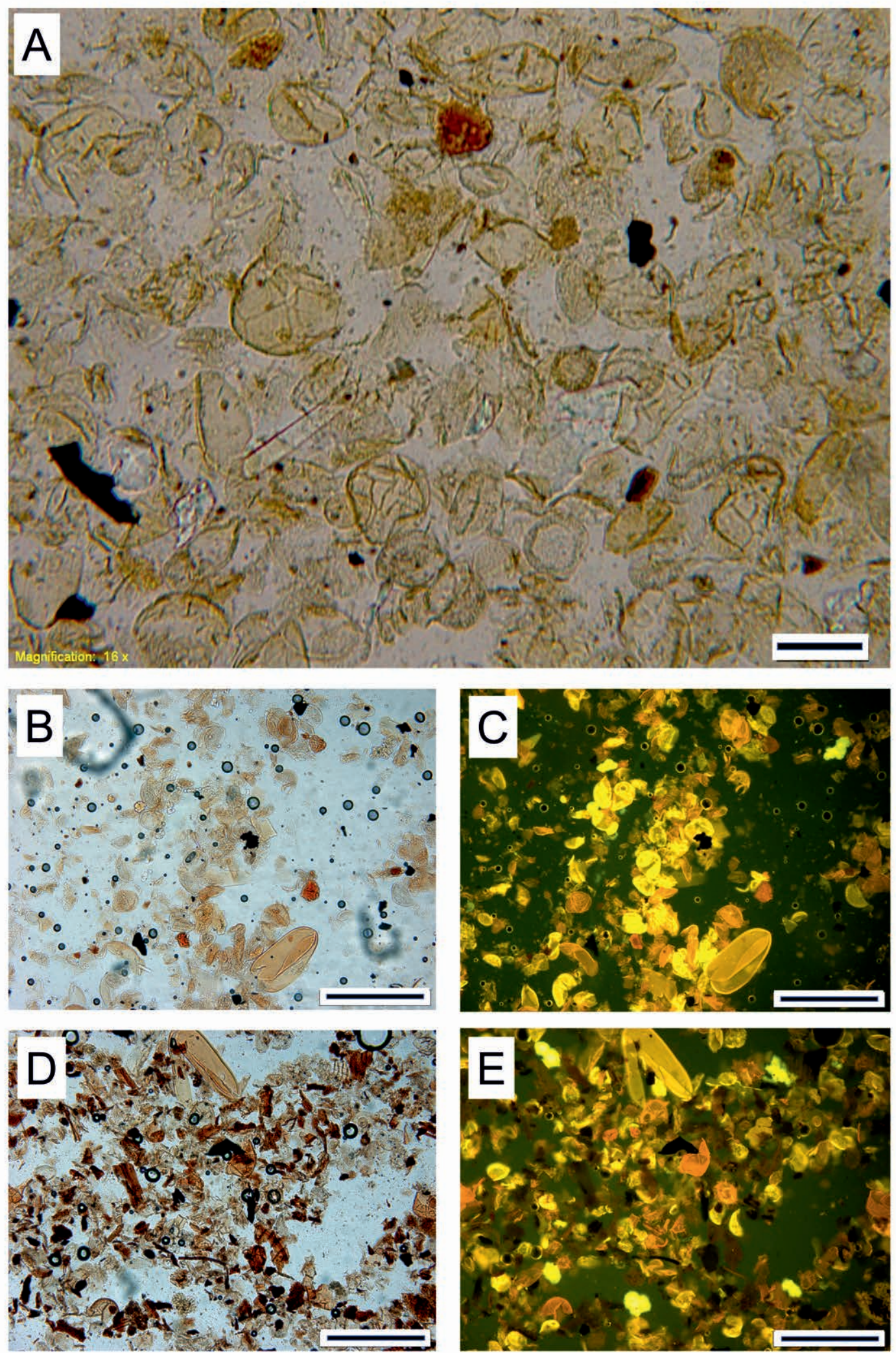

Figure 3. Palynofacies of the samples. A: Very rich macerate from D2 with predominance of amorphous organic matter (ca. 50\%) and liptinite kerogen components (ca. 40\%); scale bar $50 \mu \mathrm{m}$; B: Palynofacies with abundant sedimentary organic matter in D219 in transmitted light; scale bar $200 \mu \mathrm{m}$; C: Same in fluorescent light; D: Palynofacies very rich in organic matter from D221 in transmitted light; scale bar $200 \mu \mathrm{m}$; E: Same in fluorescent light

3. ábra. A vizsgált minták palinofáciese. A: Nagyon gazdag macerátum a D2 rétegböl jelentös mennyiségü amorf szerves anyaggal ( $k b$. 50\%) és liptinittel ( $k b .40 \%) ;$ az aránymérték $50 \mu \mathrm{m}$; B: A D219 réteg palinofáciese sok üledékes szerves anyaggal, átesô fényben; az aránymérték $200 \mu \mathrm{m}$; C: Ugyanaz fluoreszkáló fényben; D: A D221 réteg palinofáciese nagyon sok szerves anyaggal átesö fényben; az aránymérték 200 m; E: Ugyanaz fluoreszkáló fényben 


\section{Discussion}

\section{Paleoenvironmental interpretation}

Samples D3, D2, D1, D219 and D221 share a series of common features, including a high proportion of amorphous matter, lower lignohumine content, pyrite inclusions, mostly bissacate forms of pollen grains, and an abundance of dinoflagellates with a predominance of proximate dinoflagellate cysts. Thus, their palynofacies indicates a relatively distal, calm, occasionally oxygen-deficient, probably deep depositional environment (STEFFEN \& GORIN 1993, TySON 1995, SLUiJs et al. 2005).

\section{Biostratigraphic interpretation}

The biocoenosis and the detected dinoflagellate cysts of D25 bear resemblance to those of the late Sarmatian Polysphaeridium zoharyi-Lingulodinium machaerophorum Zone (BAKRAČ 2005, BAKRAČ et al. 2012), although both species may occur sporadically in the Pannonian. The thermal heterogeneity of the macerals as well as the completely oxidized dinoflagellate cysts may indicate reworking from Sarmatian or upper Badenian sediments. Forams, ostracods and mollusks all argue for a Pannonian age of D25.

The rest of the samples contained typical endemic Pannonian assemblages. Based on the presence of Pontiadinium pecsvaradensis and the lack of any younger zone markers, the D3 to D1 interval belongs to the P. pecsvaradensis Zone (e.g., SüTő-SzENTAI 1988, BAKRAČ et al. 2012) (Figure 1). In Croatia, this zone is traditionally assigned into the upper (younger) part of the upper Pannonian (s. str.), and is correlated with the so-called "Banatica layers" (Congeria banatica bearing marls; see in LUČIĆ et al. 2001). MAGYAR et al. (1999b) argued that the $P$. pecsvaradensis Zone correlates with the older part of C5n magnetic polarity zone in several wells, and its age was estimated as 10.6-10.8 Ma (MAGYAR \& GEARY 2012) or 10.65-10.75 Ma (BoTKA et al. 2020).
Samples D219 and D221 did not yield any species unambiguously marking a zone younger than the $P$. pecsvaradensis Zone; even P. pecsvaradensis itself was missing in D219. Although Pontiadinium obesum and Spiniferites maisensis, both occurring in D221, are more common in the younger zones (traditionally correlated with the Pontian in Croatia, see BAKRAČ et al. 2012), they first appear in the Spiniferites oblongus Zone that underlies the $P$. pecsvaradensis Zone. Thus, the biostratigraphic position of these layers can be given as "P. pecsvaradensis Zone or younger".

\section{Conclusions}

Six samples (out of the investigated 66) from the Pannonian marl succession of Pécs-Danitzpuszta contained wellpreserved palynomorph assemblages. Samples D1 to D3 in the middle part of the succession yielded, among others, the dinoflagellate cyst Pontiadinium pecsvaradensis, a biostratigraphic marker species ( $P$. pecsvaradensis Zone). Wellpreserved material from the top of the succession failed to contain any species exclusively characterizing biozones younger than the $P$. pecsvaradensis Zone, thus these samples either belong to the P. pecsvaradensis Zone or they are younger.

\section{Acknowledgements}

VIKTÓRIA BARANYI and an anonymous reviewer are thanked for their careful reviews and advice. This research was carried out within the framework of the HungarianCroatian bilateral project "Stratigraphy and correlation of Upper Miocene - Pliocene sediments along the CroatianHungarian border" (TÉT 16-1-2016-0004) and further supported by the OTKA/NKFIH (Hungarian National Research, Development and Innovation Office) project 116618. This is MTA-MTM-ELTE Paleo contribution No. 353.

\section{References - Irodalom}

BAKRAČ, K. 2005: Palinološka karakterizacija naslaga srednjeg miocena jugozapadnog dijela Panonskog bazena [Palinology of the Middle and Upper Miocene deposits from the south-western parts of the Pannonian Basin]. - PhD Thesis, University of Zagreb, 173 p. (in Croatian with English summary)

BAKRAČ, K., Koch, G. \& SREMAC, J. 2012: Middle and Late Miocene palynological biozonation of the south-western part of Central Paratethys (Croatia). - Geologica Croatica 65, 207-222. https://doi.org/10.4154/GC.2012.12

Botka, D., Magyar, I., Csoma, V., Tóth, E., Šujan, M., Ruszkiczay-Rüdiger, Zs., Chyba, A., Braucher, R., Sant, K., Ćorić, S., Baranyi, V., Bakrač, K., Krizmanić, K., Bartha, I. R., Szabó, M. \& Silye, L. 2019: Integrated stratigraphy of the Guşterița clay pit: a key section for the early Pannonian (late Miocene) of the Transylvanian Basin (Romania). - Austrian Journal of Earth Sciences 112, 221-247, https://doi.org/10.17738/ajes.2019.0013

Gorjanović-Kramberger, K. 1890: Die praepontischen Bildungen des Agramer Gebirges. - Glasnik Hrvatskoga Naravoslovnoga Družtva 5, 151-163.

GORJANOVIĆ-KRAMBERGER, K. 1899: Die Fauna der unterpontischen Bildungen um Londjica in Slavonien. - Jahrbuch der kaiserlichköniglichen geologischen Reichsanstalt 49, 125-134. 
Hably L. \& Sebe K. 2016: A late Miocene thermophilous flora from Pécs-Danitzpuszta, Mecsek Mts., Hungary. - Neues Jahrbuch für Geologie und Paläontologie 279/3, 261-271. https://doi.org/10.1127/njgpa/2016/0554

KocH, A. 1902: Újabb adalékok a beocsini czementmárga geo-paleontológiai viszonyaihoz. - Földtani Közlöny 32, 271-280.

Lučić, D., Saftić, B., Krizmanić, K., Prelogović, E., Britvić, V., Mesić, I. \& TadeJ, J. 2001: The Neogene evolution and hydrocarbon potential of the Panonian Basin in Croatia. - Marine and Petroleum Geology 18, 133-147. https://doi.org/10.1016/S02648172(00)00038-6

MAGYAR, I. \& GEARY, D. H. 2012: Biostratigraphy in a late Neogene Caspian-type lacustrine basin: Lake Pannon, Hungary. - In: BAGANZ, O. W., Bartov, Y., Bohacs, K. \& Nummedal, D. (eds): Lacustrine sandstone reservoirs and hydrocarbon systems. - American Association of Petroleum Geologists Memoir 95, 255-264. https://doi.org/10.1306/13291392M953142

Magyar, I., Geary, D.H. \& MüLler, P. 1999a: Paleogeographic evolution of the Late Miocene Lake Pannon in Central Europe. Palaeogeography, Palaeoclimatology, Palaeoecology 147, 151-167.

Magyar, I., GeAry, D.H., SÜTő-Szentai, M., LANTOS, M. \& MÜLler, P. 1999b: Integrated biostratigraphic, magnetostratigraphic and chronostratigraphic correlations of the Late Miocene Lake Pannon deposits. - Acta Geologica Hungarica 42, 5-31.

Magyar I., Juhász Gy., Szuromi-Korecz A. \& Sütő-Szentai M. 2004: A pannóniai Tótkomlósi Mészmárga Tagozat kifejlődése és kora a Battonya-Pusztaföldvári-hátság környezetében. The Tótkomlós Calcareous Marl Member of the Lake Pannon sedimentary sequence in the Battonya-Pusztaföldvár region, SE Hungary. - Földtani Közlöny 133, 521-540.

Moore, P. D., WebB, J. A. \& Collinson, M. E. 1991: Pollen Analysis. - Blackwell Scientific Publications, Oxford, 216 p.

Schwab, K.W. 1990: Organic Petrology Seminar (Visual Kerogen Assessment). - Geol.-Strat., Inc., Houston Texas, Zeist, Nederlands.

Sebe, K., Konrád, Gy., Sztanó O. 2021: An exceptional surface occurrence: the middle to upper Miocene succession of PécsDanitzpuszta (SW Hungary). - Földtani Közlöny 151/3, 235-252.

Sluijs, A., Pross, J. \& BRinkHUis, H. 2005: From greenhouse to icehouse; organic-walled dinoflagellate cysts as paleoenvironmental indicators in the Paleogene. - Earth-Science Reviews 68, 28-315. https://doi.org/10.1016/j.earscirev.2004.06.001

Soliman, A. \& Riding, J. B. 2017: Late Miocene (Tortonian) gonyaulacacean dinoflagellate cysts from the Vienna Basin, Austria. Review of Palaeobotany and Palynology 244, 325-346. https://doi.org/10.1016/j.revpalbo.2017.02.003.

SREMAC, J. 1981: Some new and less known species of molluscs of the Croatica-beds and the Banatica-beds in northern Croatia. Geološki vjesnik 33, 107-121.

STAPLIN, F.L. 1977: Interpretation of thermal history from color of particulate organic matter - a review. - Palynology 1, 9-18. https://doi.org/10.1080/01916122.1977.9989146

Steffen, D. \& Gorin, G. 1993: Palynofacies of the Upper Tithonian - Berriasian Deep-sea Carbonates in the Vocontian Trough (SE France). - Bull. Centres Rech. Exploration-Prod. Elf Aquitaine 17/1, 235-245, 1 Pl., Boussens.

SÜTŐ-SZENTAI, M. 1982: Organic microplanktonic and sporomorphous remains from the Pannonian from the borehole Tengelic 2. Annals of the Hungarian Geological Institute 65, 205-233.

SÜTŐ-SzENTAI, M. 1988: Microplankton zones of organic skeleton in the Pannonian s. 1. stratum complex and in the upper part of the Sarmatian strata. - Acta Botanica Hungarica 34, 339-35.

SÜTő-SzENTAI, M. 1989: Microplankton flora of the Pannonian sequence of the Szentlórinc-XII structure exploratory well. - Földtani Közlöny 119, 31-43.

SüTő-SzENTAI, M. 1994: Microplankton associations of organic sceleton in the surroundings of Villány Mts. - Földtani Közlöny 124, 451-478.

SÜTŐ-SzENTAI, M. 2000a: Examination for Microplanctons of organic sceleton in the area between the Mecsek and the Villány Mountains (S Hungary Somberek No2 borehole). Szervesvázú mikroplankton vizsgálatok a Mecsek és a Villányi hegység közötti területen (Somberek 2. sz. fúrás). - Folia Comloensis 8, 157-167.

Sütő-SzENTAI, M. 2000b: Organic walled microplankton zonation of the Pannonian s.1. in the surroundings of Kaskantyú, Paks and Tengelic (Hungary). - Annual Report of the Geological Institute of Hungary 1994-1995/II, 153-175.

SÜTŐ-SzENTAI, M. 2002: Analysis of microplanktons of organic sceleton from borehole Nagykozár 2 (S Hungary). - Folia Comloensis 11, 93-110.

Ter Borgh, M., Vasiliev, I., Stoica, M., Knežević, S., Mațenco, L., Krijgsman, W., Rundić, L. \& Cloetingh, S. 2013: The isolation of the Pannonian basin (Central Paratethys): new constraints from magnetostratigraphy and biostratigraphy. - Global and Planetary Change 103, 99-118. https://doi.org/10.1016/j.gloplacha.2012.10.001.

TYSON, R. V. 1995: Sedimentary organic matter. Organic facies and palynofacies. - Chapman and Hall, London, 591 p.

Vasiliev, I., BAKrač, K., Kovačić, M., Abdul Aziz, H. \& Krijgsman, W. 2007: Palaeomagnetic results from the Sarmatian/Pannonian boundary in North-Eastern Croatia (Vranović section, Našice quarry). - Geologia Croatica 60, 151-163.

VRsaljKo, D. 1999: The Pannonian palaeoecology and biostratigraphy of molluscs from Kostanjek - Medvednica Mt., Croatia. Geologia Croatica 52, 9-27. https://doi.org/10.4154/GC.1999.02

Manuscript received: 08/06/2021 